\title{
Women's participation in education and training in New Zealand: Is the 'learn while you earn' option accessible to all?
}

\author{
Gloria Abernethy \\ Bay of Plenty Polytechnic \\ Gemma Piercy \\ University of Waikato
}

Nicky Murray

\begin{abstract}
Strong education and training systems are viewed as a route to increased labour market participation for groups who have traditionally been excluded from, or marginalised in, the labour market. Engagement in the labour force for such groups contributes to a better quality of life for the individual and has the added benefit of helping to address the demographic imperative to maximise the pool of available labour in the face of a shrinking workforce.
\end{abstract}

However, while this emphasis on an increased role for the state in education and training is encouraging, commentators such as Stalker (2000) have questioned the ability of Third Way discourse to meet the unique needs of women, given the absence of explicit feminist dialogue in wider discussions on associated policy and practice. Informed by this critique, this article aims to evaluate changes in education and training policy and practice in New Zealand since 1999, in terms of the extent to which it does - or does not - enhance opportunities for women's participation in education and training. In doing so, the article will firstly examine how changes to the nature of work lead to the need for greater inclusion of marginalized groups. Second, the changes to education and training policy and practice to facilitate greater inclusion will be outlined. Third, a small case study will be provided that demonstrates how these changes and their implications for women have been recognized by a provider of traditional trades-based education and training. 


\section{Introduction}

Despite a greater equality of opportunity which the 'knowledge society' seems to promise, and the growing perception that girls are in some way advantaged in the contemporary education and training system, women remain substantially underrepresented in industry training in New Zealand. Part of the reason for this is simply a reflection of the smaller proportion of women who work in industry: the 'engine room' of our society remains male-dominated. But the nature of work which women tend to perform: part-time, casualised and in support roles, also means they are less likely than men to receive training.

Proponents of Third Way ideology argue that access to education and training is a key mechanism to ensure social inclusion (Eichbaum, 1999; Powell, 2003). Thus, the uneven nature of women's participation in industry training can be seen as a form of social exclusion and, as such, it is a part of the education and training system worth examining. It is for this reason that the article focuses particularly on the industry training system in New Zealand and the patterns of participation by women within it.

The purpose of this article is to evaluate the extent to which education and training policy enhances opportunities for women's participation in education and training. This article draws on Girls can do anything? Women and industry training in New Zealand (Murray, 2004), Girls seeking jobs in the trades (Abernethy, 2004) and publications by Piercy on industry training and the Third Way in New Zealand (2003a; 2003b), in order to trace the impact of the reforms to the education and training system since the change of Government in 1999. The article will first, provide a brief synopsis of the historical background to women's participation in education and training; second, briefly outline how changes to the nature of work lead to the need for greater inclusion of marginalized groups; third, examine the changes to education and training policy. Finally, a small case study will be provided in order to demonstrate how the changes and their implications for women have been recognized by a provider of traditional trades based education and training. 


\section{Historical Background}

In order to assess whether or not education and training policy can make a difference in the paid working lives of women it is useful to briefly trace the history of women's participation in the New Zealand labour force. For example, although women were rarely directly excluded from an occupation, apprenticeship regulations were one means used to restrict their employment. Thus, the New Zealand arbitration system 'systematized, structured and sustained the segmentation of the labour force', allowing male workers to protect their jobs, their skilled status and their pay rates from the threat of cheaper female labour (Robertson, 1991, p.33).

Throughout the 1960s, some women began to question the stereotypical roles that held them in the home and, by the early 1970s, conditions were ripe for the re-emergence of active feminism. Within this more ambitious framework for women's empowerment, it became clear that equal pay legislation alone was insufficient to address the disadvantages and discrimination that women faced in the work place. The low number of women apprentices, and the narrow range of industries in which they were concentrated, became of concern.

In 1975, in response to continuing concerns about the disadvantages that women faced in the workforce, the Women's Advisory Committee of the Vocational Training Council (VTC) was established. This committee was instrumental in setting up 'positive action' programmes in the late 1970s and early 1980s. The Department of Labour also began a number of local initiatives, notably the 'Positive Action' campaign that was launched in late 1982. This programme was designed to move women out of the small number of occupational groups to which they were largely confined (Martin, 1996). At the end of 1984, the Labour Department established a Positive Action Programme for Women, with the catch-phrase: 'Girls Can Do Anything' ('Positive action programme appointments,' 1985). The programme used the existing resources of the Labour Department to 'promote wider job horizons for girls and women and to identify and promote training and employment opportunities in non-traditional areas of work' (AJHR, 1985, G-1, p.23). 
By 1987, however, 'positive action' programmes began to fall victim to economic and political changes. Employment patterns were altered by economic restructuring and new technologies (AJHR, 1988, G-1). It was felt that the limited success rates of increasing women's participation in non-traditional trades training during the mid 1980s, coupled with the downturn in many of those trades, suggested that effort was better placed in encouraging women into new occupational areas. These changes, by both government and industry, will be outlined in the next section, which focuses on changes to the nature of work.

\section{Changes to the Nature of Work}

Globalisation, in the form of the increased internationalisation of capital in the 1970s, began to raise the level of competition between nation states with some countries challenging traditional management styles and structures (Jurgens, Malsch, \& Dohse, 1993). Littler (1991), cited in Law (1996, p.164), argues that there was an 'acceptance internationally that significant changes were occurring in workplace relations and work organisation'. Mathews (1989) holds that these changes in production were also influenced by changes in technology which altered the nature of work in the manufacturing sector and in the service sector. Mathews (1989) claims that during the introduction of these new management practices and technology, jobs were both lost and created as those requiring computer skills were created and unskilled assembly jobs became redundant. He adds that the constant changes resulting from the alterations to technology and the need to improve quality requires workers to be able to learn continually for their working lifetimes.

In New Zealand, these wider international changes to the nature of work were accompanied by domestic regulatory changes. These reforms began with the election of the Fourth Labour Government (1984-1990) and the implementation of Rogernomics. Deeks et al (1994) identify the main features of 'Rogernomics' as:

- a reduction in tariffs;

- deregulation of the market through the removal of exchange and interest rate controls; 
- reconstruction of the public sector, privatisation and sale of the state assets;

- the transport and banking industry deregulation;

- loss of export incentive and producer subsidises; and

- the discontinuation of import licensing and state trading monopoly rights.

They add that this took New Zealand from being 'one of the most highly regulated economies in the western world to one of the least regulated' (p.66). Labour was defeated in 1990, by National, who then implemented a series of administrative and legislative changes that took New Zealand further down the neo-liberalism road than almost any other country. With respect to the labour market, the Employment Contracts Act (1991) (ECA) fundamentally transformed the labour market, and the role of the state.

The economic restructuring implemented by the Fourth Labour Government occurred so swiftly that workers who lost their jobs could not be effectively absorbed into the labour market. Thus, Deeks, Parker and Ryan, (1994, p.397) report that: 'between September 1986 and March 1992, the unemployment rate rose from 3.8 per cent to a peak of 11.1 per cent.' The net result of the speed of the structural adjustment through the 1980s was 'to take labour out of manufacturing and onto the unemployment register or out of the labour force altogether' (Morrison, 1991, p.14). New Zealand's burgeoning unemployment rate from the mid-1980s was thus largely due to the decline in the manufacturing sector. From 1986 to 1991 there was a net decline in employment of 111,500 persons, with the manufacturing sector having a net loss of 102,400 persons (Krishnan, Hunter \& Goodger, 1992). In contrast, in the 15 years prior to 2002, three broad service industry groupings added more than 90 per cent of new jobs: wholesale and retail trade, restaurants and hotels; finance, property and business service; and community, social and personal services, while employment in the primary sector and manufacturing remained static or declined (Department of Labour, 2003e). 


\section{Changes in Policy and Post-compulsory Education and Training}

The introduction by the National government of a voluntaristic, industry-led training regime in the early 1990s, premised on individual responsibility in a voluntarist environment, did little to improve the traditionally poor position of women in apprenticeship/industry training (Piercy, 1999). The risks posed to women's participation in industry training by a market-orientated model were signposted by Pocock (1992) in research that compared entry-level training for women over several countries. She found that industry-led training systems first tended to constrain access to training and, second, tended to reinforce poorer outcomes for those women in training: 'Placing overall control of entry level training in the hands of industry - without a firm legal framework and frequent monitoring - will widen...gaps and replicate and reinforce women's secondary status' (Pocock, 1992, p.ii).

\section{The Third Way and social inclusion}

In a Third Way context, education and training is seen as an area where government policy can have a more direct influence. The policies currently in place in New Zealand tread a fine line between prescription and facilitation and this section examines these policies in order to assess their impact.

The Third Way is a contested term that has often been pinned to political platforms in countries that have attempted to reconcile the traditional aims of socialism with the changing nature of globalised capitalism and/or neo-liberal economic imperatives (Giddens, 2000; Powell, 2003). Each country where this type of agenda has been pursued constitutes a different historical and political context, so variations have naturally occurred when meeting the needs of those contexts, including New Zealand (Eichbaum, 1999). However, what is clear is that certain developed countries have been 'pursuing policies that have some new and distinctive elements' (Powell, 2003, p.106). These include:

- an emphasis on the role and importance of community, and other stakeholder groups and a need to consult with them; 
- government acceptance of a role in relation to provision of equal 'opportunity';

- a role that relates particularly to the provision of opportunities to work and contribute to the economy as well as society

- placement of responsibility on those who receive government facilitated opportunities in the form of accountability;

- leading to increased social inclusion for those citizens who are able to make the most of their opportunities.

It has also altered how policy is created and shaped. Policy must now be evidence based and driven by results and not ideology. For example, the Blair Government in Britain has stated that it seeks a more ambitious and dynamic redistribution process. Instead of compensating people for their poverty with transfer payments, it aims to increase opportunities by increasing poor people's level of health and education (Powell, 2003, p.104). With these elements in mind, the welfare state moves from being a safety net to being the provider of opportunity. Work becomes the surest route out of poverty. Social justice is to be achieved by a redistribution opportunities rather than a redistribution of wealth income.

Powell (2003) argues that under a Third Way ideology, solutions to poverty and inequality are not simply addressed by transfer payments but instead by increased investment in health and, more significantly for this article, in human capital or education. Thus, investment in human capital via workplace learning or industry training is one policy area in which the Third Way seeks to promote and create social cohesion by ensuring citizens have access to meaningful and decent work. Under these assumptions, the rhetoric of lifelong learning becomes an imperative as the impact of globalisation and international competition contribute to job insecurity. Upskilling and reskilling are seen as key forms of investment in human capital to ensure that citizens still have access to the labour market (Powell, 2003). How this Third Way emphasis on investment in education and training is reflected in current policies is the subject of the following discussion. 


\section{A new direction}

The publication of Chatterjee, Conway, Dalziel, Eichbaum, Harris, Philpott, and Shaw (1999) The New Politics: A 'third way' for New Zealand imported many of the ideas popularised by Giddens and Blair. The book sketched a way to pursue social democratic ideals in a (post?) neo-liberal landscape (Law, 2004). But while the authors drew on much of the Blair Government's policies and practices, they did not do so uncritically. Significantly, the New Zealand authors advocated a much more active role for the state than did Giddens. This paved the way for an adaptation of 'Third Way' ideas rather than simply their adoption (Law and Piercy, 2004). In this sense, the 1999 volume can be seen as an important bridge between the policies of the 1990s and those of the 2000s.

This change in emphasis was also reflected in Labour's 1999 manifesto documents and in its post-election policies. An example of this is the 1999 election manifesto document $21^{\text {st }}$ Century Skills: Building Skills for Jobs and Growth. This document outlined the limitations of the industry training system implemented by the National-led Governments (Murray, 2000; Piercy, 1999). In the following section, the key tertiary policies implemented in the first two terms of the Labour-led government will be briefly examined.

\section{The Tertiary Education Strategy}

In the early 2000s, the Tertiary Education Advisory Commission reviewed the postcompulsory education and training (PCET) sector. The report process resulted in the formation of the Transition Tertiary Education Commission. One of their first actions was to create a five-year plan, the Tertiary Education Strategy (TES). The TES incorporates and reflects key assumptions of human capital theory, particularly those which were developed in response to the 'need' to be internationally competitive and for workers to embrace lifelong learning as a result of changes to the nature of work. Significantly for this paper, the TES also demonstrates the Third Way assumption that access to education will lead to increased employment opportunities for the wider society, which in turn will lead to greater social cohesion or inclusion (Eichbaum, 1999). 
The six strategies of the TES that aim to lead to this greater social inclusion are to:

- $\quad$ strengthen system capability and quality

- contribute to the achievement of Maori development aspirations

- raise foundation skills so that all people can participate in our Knowledge Society

- develop the skills New Zealanders need for our Knowledge Society

- educate for Pacific Peoples' development and success

- $\quad$ strengthen research, knowledge creation and uptake for our Knowledge Society

The TES is being implemented by a phased process where steering mechanisms are used to push the tertiary sector into contributing to the goals above. The steering mechanisms are a transparent set of practical guidelines with a funding system that includes targets and goals developed in partnership with government and stakeholder. This approach allows Government priorities to guide the planning of both Tertiary Education Organisations (TEOs) and government departments and agencies but not at the expense of innovation and responsiveness (Ministry of Education, 2002a).

Some of the changes that have occurred as a result of policy reform include:

- the revitalisation of apprenticeship through the introduction of both the TES and the Modern Apprenticeship ${ }^{1}$ system;

- increased involvement on the part of Polytechnics in the provision of trades training; and

- establishment of a central planning and funding government body called Tertiary Education Commission

\footnotetext{
1 Modern Apprenticeships are administered by the Tertiary Education Commission and: provide systematic, high quality workplace learning; are aimed primarily at sixteen to twenty-one year olds; are based on a training agreement, signed off by employer and apprentice; lead to national qualifications at Levels 3 and 4 on the NQF; cover generic and specific skills; extend apprenticeship to non-traditional industries; and complement existing education/training options The essence of the programme is the appointment of Modern Apprenticeships Co-ordinators, who recruit and place apprentices, support and facilitate their training and mentor them (Skill New Zealand, 2001).
} 
- introduction the Charter and Profile in order to determine funding levels and to monitor, gather and analyse information about TEOs in order to assess for their strategic relevance, performance, and participation;

- a greater leadership role for industry training (Ministry of Education, 2003b) aimed at supporting industries in identifying and meeting their skills needs

\section{The Tertiary Education Strategy and women's participation in training}

One of the main reasons for improvements in women's participation has been a significant increase in educational opportunities. Access has been gained through initiatives such as the TOP and Skill Enhancement programmes. The student loan scheme has had a significant impact, one the one hand by providing access and on the other hand as a disincentive when women's lower incomes could lead to them taking longer to repay loans (CEDAW, 2002). These developments were shown as particularly significant for Maori women, who were more likely than pakeha to have left school with no qualifications, to be sole parents and to be receiving social security benefits, as well as to be more likely to face barriers to employment (CEDAW, 1998).

\section{Participation by women in education and training programmes since 1999}

As at December 2002, women represented 46 per cent of the labour force, but only 24 per cent of industry trainees were women (Tertiary Education Commission, 2003a). An analysis of women in industry training between 2000 and 2003, carried out by the Industry Training Federation, identified even more worrying trends when this low level of participation was further disaggregated by industry. While the number of women in industry training increased by around 64 percent (from 12,962 in 2002, to 21,338 in 2003), a markedly greater increase than the total growth in numbers of industry trainees (43.1 per cent), 45.5 per cent of this growth was attributable to just two Industry Training Organisations (ITOs) - the Community Support Services ITO $(2,403)$ and the Hospitality ITO $(1,410)$. In general, 'service and care-related industries are major centres of female participation' (Curson et al., 2004, p.9). 


\section{Modern Apprenticeships}

An analysis of 'Modern Apprenticeships' reinforces the picture of disadvantage that women face in accessing industry training. As at March 2003, only 6.2 percent (315) of the 5,102 Modern Apprentices were women. A factor in this gender disparity is that apprenticeships remain concentrated in what could be considered 'traditional' apprenticeship industries. Since the inception of Modern Apprenticeships, eight of the larger industries (all with a history of apprenticeship training) have accounted for a steady two-thirds of trainees. As at 31 March 2003, those eight industries employed 67 per cent $(3,427)$ of all apprentices, but only 38 per cent $(120)$ of all female Modern Apprentices. Conversely, nearly 30 per cent (86) of female apprentices were concentrated in just four industries: hospitality, public sector, retail and tourism, which employed a tiny 3.4 per cent (174) of all Modern Apprentices (Tertiary Education Commission, 2003b). ${ }^{2}$

When the fact that the gender imbalance of the Modern Apprenticeships scheme became a 'subject of international employment rights scrutiny', McGregor \& Gray (2003) were asked to prepare a report for the Human Rights Commission. Their findings reinforced the dangers of relying on broadening the range of industries in the scheme alone as a means to ensure greater equity (2003). As has been seen with industry training, women have remained concentrated in lower paid service sector industries, or within 'support' capacities in male-dominated industries. There is little to suggest that increasing the number of female Modern Apprentices in industries such as tourism, retail or hospitality, or extending the scheme to 'female-friendly' industries, would result in significant improvements in terms of women's pay levels.

Given the limited success in policy driven attempts to change the pattern of women's participation in industry training, it is timely to investigate how TEOs attempt to create change by working from within the industry training systems. In the next section we present one institution's examination of the need for change in regard to women's participation under the new policies.

\footnotetext{
${ }^{2}$ Provide updated figures?
} 


\section{Case study: Girls seeking jobs in the trades}

This research was undertaken by Gloria Abernethy and Dawn Douch in 2003. The aim was to identify the performance of the School of Applied Technology over the last three years in supporting the success of women, fulltime students in one year, pre-trade programmes; that is, automotive, boat building, carpentry, electrotechnology and engineering. There are complexities and sometimes contradictions in the access and participation of women in both training and employment in the traditional male trades. Nevertheless some women have succeeded in negotiating the pathway from personal interest to skilled employment. It is with these factors, both the contradictions and success, in mind, that a project was proposed to ask a small group of women graduates, of one year full time polytechnic pre-trade programmes, about their experiences as they sought employment after their training. In particular, the project was intended to present the stories of respondents as they recounted their experiences in their own words, as they made the transition from training to employment and to identify factors they perceived influenced their success in gaining employment in related fields. It was expected that the findings would highlight issues and opportunities that could be explored in further projects.

\section{Methodology}

This investigation was a dual design, incorporating analysis of quantitative data ${ }^{3}$ already collected by the Bay of Plenty Polytechnic face to face semi-structured interviews that allowed respondents to talk freely and share their experiences. The respondents were selected from a list compiled from Bay of Plenty Polytechnic's retention and success statistics for 2002-2004, of women who had enrolled in one-year, fulltime pre-trade programmes in carpentry; automotive; engineering; electrotechnology and boat building programmes; areas seen as traditionally male domains. Thirteen potential respondents were identified once contacted this reduced down to six of whom four agreed to an

\footnotetext{
${ }^{3}$ Subject Retention Analysis Report, is collated after the end of each academic year, has been collected at Bay of Plenty Polytechnic from 2002 onwards; thus there are three complete years of consistent data from which to make comparisons. These statistics were analysed to provide a context for the participation and success of these women in one-year, fulltime, pre-trade programmes in the School of Applied Technology at Bay of Plenty Polytechnic.
} 
interview. Two of the four had returned to polytechnic for further training and were able to interview them at the polytechnic, and the remaining two were interviewed at home.

\section{Findings}

There were four respondents for this case study, who represented diverse factors:

- two were Maori and two pakeha;

- two were mothers;

- one entered the trade programme directly from school; the others after a break from education;

- two had returned to polytechnic for further training after failing to gain employment and retained the desire to gain an apprenticeship;

- two gained employment in an industry related to that of their training, but not as apprentices.

\section{Individual participation}

The women demonstrated a strong sense of their own agency or role; in that they believed opportunities exist for them and that it was their choices and achievements that would make the difference. They expressed this in their motivations for training and passing their programmes:

I want to make a future for myself and my child

... paying for the course

you've got to want to be there, definitely having passion

... wanting to pass

I found what I want to do with my life

Ownership of the need for perseverance and achievement was clearly identified:

The course puts out a lot of opportunity, basically you take it if you want to

... perseverance, make yourself keep going, turn up every day

once I've finished this year, passed this course, got my qualification 
All expressed optimism that there was a place for them in the industry in which they had trained:

... it's starting to get easier. Somewhere along the line, someone's gonna want to employ me

I want to stay in the automotive industry for the rest of my life, because that's what interests me and that's what I want in a job

I love it. I've been here every day. They are training me up.

\section{Institutional progress}

These women indicated that the polytechnic and employers were contributing to their success. They named the quality of their tutors and the learning support they received while at polytechnic as major factors:

I think the tutors were really good, that was the main thing

The tutors gave you so many options on how to do things

We did have one on one with the tutor a lot of the time

... tutors and the practical work - the chance to do all the jobs/skills

... at polytech if you need help you can get it

they said you don't have to turn up but you will fail if you don't. It starts you thinking and it makes you want to come

Then respondents stressed the importance of work experience, both to practise skills and gain access to industry:

Work experience is the key

It was like I was another worker, so it was good

... the practical experience

The polytechnic and tutors are viewed as an important link with industry for women students. Tutors do not find work experience for students; so they encourage students' independence and meeting the early realities of the job search process. Tutors do pass on work opportunities when employers ask for students to apply for job vacancies. They have a role here in encouraging women on the same basis as the males, to present the 
skills they have gained in the programmes. The strong relationship with industry varies among teams, however, and one respondent commented that:

It would be more ideal [with the tutor] trying to make use of the avenue, cos once I left the polytech I found I wasn't in the industry, I didn't know any of these people

When seeking work experience, women met resistance, but also persevered, to find workplaces willing to take them on and provide positive and useful experiences.

\section{Contradictions}

Respondents expressed optimism that there was a place in industry for women, however they also recognised that there were barriers, when on work experience and when seeking fulltime employment. Respondents displayed their frustration at not being given tasks where they could use and improve their skills on work experience:

The employer wouldn't let me do the work ... he wasted my time and money I was just like a tagalong, didn't get that much hands on experience

The guys didn't take me seriously because I was a girl and it was a big company

The behaviour of males in the workplace also impacted on their experience:

Well, workshop guys in general, how they look at you, how they speak to you ... quite shocking

I think you've got to put your foot down sometimes

... being a female, at times you find you have to work twice as hard just to prove yourself

When seeking employment, they experienced direct rejection:

It was wow, a lady, um, oh no, we're not looking for anyone I've been trying to get into an apprenticeship for years now I worked for free, then they told me they weren't taking anyone on and two days later they employed someone from the course - he didn't even finish the course 
There were also indirect effects, in that they seemed to view non-success as a deficit in themselves rather than discrimination:

I think I might have been a bit young

The more you got on article, the more interested they seem ... it must just come down to experience

Being a mother first, I guess they saw as being a not always reliable apprentice

The cost of training appeared to be a reality that was accepted as inevitable:

My hardest times have been pretty much just trying to get in there, getting an apprenticeship, cos I didn't want to come to the polytechnic and get student loans, that's why I did the other course first, but no-one would take me from there, and that's pretty much why I've done the second year too [at polytechnic]

I came back for the second year because of the fear factor [being rejected] and I didn't have my own tools, so that I wouldn't get an apprenticeship.

\section{Reflections}

Although this was a very small case study, the respondents provided rich qualitative data, for industry facing a growing skills shortage and for policy makers who have called for women's participation in industry. The experiences recounted by this group of graduates have revealed issues that are by no means peculiar to these individuals but to female workers in industry through New Zealand.

\section{Conclusion: Contradictions and the right to get dirty...}

The purpose of this article was to evaluate whether or not the changes in education and training policy and practice in New Zealand since 1999 have enhanced opportunities for women's participation in education and training. The increase in participation figures demonstrates that some changes are occuring but the segregation of male and female participation indicates that barriers still remain. The continued trend of omitting to

specifically target female workers in policy challenges the ability of the reforms to directly impact on women's lives and contribute to increased social inclusion. 
Given that women's overall participation in industry training is low, and that those women who do participate tend to be concentrated in the lower-paid service and care sectors, it is necessary ask why this is so. Curson et al (2004), while recognising the need for greater research, suggested two possible reasons. First, women have 'embraced provider-based education at a faster rate than men', with women accounting for 58 per cent of all enrolments at tertiary education providers in 2002 (Curson et al., 2004, p.17).

Second, Curson et al (2004) suggested that 'there may be a lack of suitable training options for the positions that women tend to occupy within an industry' (Curson et al., 2004, p.20). This vertical gender segregation was in evidence, for example, in an analysis carried out in 2002 by the Electricity Supply ITO, which showed that the majority of women involved in the industry worked in clerical, management or professional roles areas where industry training was either not appropriate, or was not regarded as a priority by employers (Curson et al., 2004).

A third possible reason for low levels of participation and segregated nature of that participation is that there may be explicit or implicit discrimination against them accessing an industry, or training within that industry. However, Cockburn (1999), writing about women in engineering, argues: 'men's greater average physical stature and strength are often cited as a reason for men's preponderance in engineering occupations. Yet it is not self-evident that they should be all male. Many machines, from the lever to the mill, have been developed precisely to substitute for human physical strength' (Cockburn, 1999, p.127).

A fourth reason may also be suggested for the low levels of women's participation in industry training: they are simply not interested. McGregor \& Gray (2003) argued that parents, who are the main source of information and careers advice for many secondary students (Boyd, Chalmers, \& Kumekawa, 2001): 'have traditionally seen apprenticeships as a pathway for non-academic young men' (McGregor \& Gray, 2003, p.1). 
It is clear that policy makers must direct their energies to producing policy that directly and specifically refers to women and the ways in which they can be encouraged into industry training. As Connole (1997) argued, governments must cease designing 'training arrangements for young men and then making unsatisfactory running repairs to the system to accommodate women and other equity groups' (Connole, 1997, p.1). McGregor \& Gray (2003) reported that the Tertiary Education Commission's rather 'hands-off' approach to improving the gender balance of the scheme, which relied on advertising and broadening the range of industries offered as discussed above, was shortsighted: "the greatest opportunity for making a difference with regard to these underrepresented groups is to put in place initiatives early so that the structural inequalities of the past apprenticeship system are not replicated' (McGregor \& Gray, 2003, p.13). Finally, given skill shortages in many industries, and changing demographics that suggest many of these shortages are structural, rather than cyclic, recruiting from, and limiting training to, only half of the population is no longer sustainable. 


\section{References}

Abernethy, G. (2004). Girls seeking jobs in the Trades. Paper presented at the Vocational Education Research Forum: Industry Training Federation, Hotel Intercontinental, Wellington: 11 June 2004.

Appendices to the Journal of the House of Representatives.

Adelman, C., Jenkins, D. \& Kemmis, S. (1976). Rethinking case study: Notes from the second Cambridge conference. Cambridge Journal of Education, 6(3), 139-150.

Boyd, S., Chalmers, A. \& Kumekawa, E. (2001). Beyond school: Final year school students' experiences of the transition to tertiary study or employment. Wellington: NZCER.

CEDAW (1998). The Status of Women in New Zealand. Article 10, Education. Article 11, Employment. Wellington: Ministry of Women's Affairs. Retrieved September 12, 2000, from http://www.mwa.govt.nz/women/status/cedaw010.html

CEDAW (2002). New Zealand's $5^{\text {th }}$ Report: The status of women in New Zealalnd. Article 10 Education, Article 11, Employment. Wellington:Ministry of Women's Affairs. Retrieved March 15, 2005, from http://www.mwa.govt.nz/women/status/cedaw.html

Cleary, P. (2002, 19 August). Business failing the skills test [Website]. Financial Review. Retrieved 27 August, 2002, from the World Wide Web: http://afr.com/australia/2002/08/19/FFXIARS905D

Cockburn, C. (1999). Caught in the wheels: the high cost of being a female cog in the male machinery of engineering. In D. MacKenzie \& J. Wajcman (Eds.), The social shaping of technology (2nd ed.). Buckingham, Philadelphia: Open University Press.

Connole, H. (1997). Making training work for women: A qualitative study of women's experience in VET [Website]. TAFE NSW. Retrieved 10 May, 2004, from the World Wide Web: www.tafensw.edu.au/publications/gendequi/womcont.htm

Curson, R., Green, N., \& Hall, D. (2004). Women in industry training, 2000-2003. Wellington: Industry Training Federation.

Deeks, J. Parker, J. \& Ryan, R. (1994). Labour and employment relations in New Zealand. Auckland: Longman Paul.

Department of Education. (1988). Learning for life: Education and Training beyond the age of 15. Wellington: Author.

Department of Education. (1989). Learning for life Two: Education and Training beyond the age of 15: Policy Decisions. Wellington: Author. 
Department of Labour. (1975). Women in the workforce series, facts and figures, Supplement No. 2. Wellington: Research and Planning Division.

Department of Labour. (2003). Work trends: How work is changing in New Zealand.

Wellington: Future of Work Project, Department of Labour.

Department of Labour. (1984-1993). Annual return of apprentices. Wellington:

Department of Labour.

Department of Labour. (2004). Skills in the labour market - February 2004. Wellington: Department of Labour.

Dunstall, G. (1996). The social pattern. In G. W. Rice (Ed.), The Oxford History of New Zealand (2nd ed., pp.451-481). Auckland: Oxford University Press.

Eichbaum, C. (1999). The Politics and Economics of the Third Way. In S. Chatterjee, P. Conway, P. Dalziel, C. Eichbaum, P. Harris, B. Philpott, R. Shaw, The New Politics: A third way for New Zealand. Palmerston North, New Zealand: Dunmore Press.

Elder, S. \& Johnson, L.J. (1999). Sex-specific labour market indicators: What they show. International Labour Review, pp. 447-465. Geneva: International Labour Organisation.

Else, A. \& Bishop, B. (2003). Occupational patterns for employed New Zealand women: An analysis of the 2001 census data. Wellington: Ministry of Women's Affairs.

Equal Opportunities Commission. (2004). Plugging Britain's skills gap: Challenging gender segregation in training and work. UK: Equal Opportunities Commission.

Giddens, A. (2003). Sociology. (4 $4^{\text {th }}$ ed). Cambridge: Polity Press.

Giddens, A. (2000). The third way and its critics. Cambridge: Polity Press

Jurgens, U., Malsch, T. \& Dohse, K. (1993). Breaking from Taylorism: changing forms of work in the automobile industry. Cambridge: Cambridge University Press.

Krishnan, V., Hunter, A. \& Goodger, K. (1992, November 12 \& 13). Work trends in NZ. Proceedings of the Fifth Labour, Employment and Work in New Zealand Conference, Victoria University of Wellington. 
Law, M. (1996). Workers' education and training in a new environment. In J. Benseman, B. Findsen \& M. Scott (Ed.s), The fourth sector: Adult and community education in Aotearoa/New Zealand (pp. 159-176). Palmerston North: Dunmore Press.

Law, M. (2004). Social partnership: Rebuilding union capacity through education. In D. E. Clover (ed.). Adult education for democracy, social justice, and a culture of peace. Proceedings of the $45^{\text {th }}$ Adult Education Research Conference and the $25^{\text {th }}$ Conference of the Canadian Society for the Study of Adult Education. (322-327) Victoria, British.Columbia: University of Victoria

Law, M. and Piercy, G. (October 2004). The 'knowledge society' or the 'knowledge economy': Does it really matter? Paper presented to ESREA Network Conference: Learning Participation and Democracy, Barnham, Britain.

Martin, J. E. (1996). Holding the balance. Christchurch: Canterbury University Press.

Mathews, J. (1989). Tools of change: New technology and the democratization of work. Sydney: Pluto Press.

McGregor, J. \& Gray, L. (2003). Modern Apprenticeships: Training for the boys? (An Equal Employment Opportunities Discussion Article). Auckland: Human Rights Commission.

Ministry of Economic Development, Ministry of Social Development, Department of Labour \& Statistics New Zealand. (2003). Population and sustainable development 2003. Wellington: Ministry of Economic Development.

Ministry of Education. (2002a). Tertiary Education Strategy 2002/07. Wellington: Author.

Ministry of Education. (2003b). Statement of Tertiary Education Priorities 2003/04. Press Statement. Wellington: Author.

Montgomerie, D. (1989). The limitations of wartime change. New Zealand Journal of History, 23(1), pp.68-86.

Morrison, P. S. (1991). Job loss and unemployment in New Zealand during the 1980s. (Working Paper No 8). Wellington: Department of Geography, Victoria University.

Murray, N. (2001). A history of apprenticeship in New Zealand. Unpublished Master of Social Science Thesis, Lincoln University, Lincoln. 
Murray, N., (2004). 'Girls can do anything?' Women and industry training in New Zealand. Conference presentation, Industry Training Federation Research Forum, 11 June 2004. Wellington.

National Advisory Council on the Employment of Women. (1994). Women's access to industry training. Wellington: NACEW. New Zealand Statutes.

Nolan, M. (1993). Politics swept under a domestic carpet? New Zealand Journal of History, 27(2), pp.199-217.

O'Regan, M., (1980). Apprenticeships - jobs for the boys? Broadsheet, 83, pp.14-18. Auckland: Auckland Women's Liberation (N.Z.)

Piercy, G. (1999). Strategy and vision: The influence of the AMWU on the NZEU 19871992 with respect to education and training reforms. Unpublished MSocSc Thesis, University of Waikato, Hamilton, New Zealand.

Piercy, G. (2003). A 'third way' in industry training: New Zealand's adaptation of selected British policies. In C. H. Jorgensen \& N. Warring (Eds.), Adult education and the labour marketVII. Vol. A, (pp. 35-62).

Piercy, G. (2003b). Modern Apprenticeship: A third way in industry training? [CDROM]. Reflections and New Directions: Association of Industrial Relations Academics Australia and New Zealand Conference 2003. Monash University, Melbourne: AIRAANZ, Paper from: Volume 2 Non-refereed papers File: Piercy Modern Apprenticeships Item.

Powell, M. (2003). The Third Way. In P. Alcock, A. Erskine, and M. May, The Student's Companion to Social Policy. (2 ${ }^{\text {nd }}$ Ed). (pp.100-106). Blackwell Publishing Ltd, Melbourne.

Pocock, B. (1992). Women in entry-level training. Canberra: Commonwealth of Australia. Positive action programme appointments. (1985, June). Labour and Employment Gazette, 35, p.30.

Robertson, S. (1991). Women workers and the New Zealand Arbitration Court, 18941920. Labour History, 61.

Ryan, P. \& Unwin, L. (2001). Apprenticeship in the British 'Training Market'. National Institute Economic Review, 178, pp.99-114.

Skill New Zealand. (1998a, September). Equity afloat. Skills.

Skill New Zealand. (2001). Modern Apprenticeships News. Wellington: Skill New Zealand. 
Stalker, J. (2000). The third way and feminist imaginings. In T. Sork, V. Chapman and R, St Clair, Proceedings of the $41^{\text {st }}$ Annual Adult Education Research Conference (438442). Vancouver: The University of British Columbia, June 2-4, 2000.

Steedman, H. (2001). Five years of the Modern Apprenticeship initiative: An assessment against continental European models. National Institute Economic Review, 178, pp.7587.

Tertiary Education Advisory Commission. (2000). Shaping a shared vision. Author, Wellington.

Tertiary Education Advisory Commission. (2001a). Shaping the system. Author, Wellington.

Tertiary Education Advisory Commission. (2001b). Shaping the strategy. Author, Wellington.

Tertiary Education Advisory Commission. (2001). Shaping the Funding Framework. Wellington: TEAC.

Tertiary Education Commission. (2003a). Industry Training 2002. Wellington: TEC.

Tertiary Education Commission. (2003b). Modern Apprentices as at 31 March 2003. Wellington: TEC. 